\title{
Biological Control of Late Leaf Spot of Peanut (Arachis hypogaea) with Chitinolytic Bacteria
}

\author{
G. Krishna Kishore, Suresh Pande, and A. R. Podile
}

First and third authors: Department of Plant Sciences, University of Hyderabad, Hyderabad 500 046, India; and second author: Legumes Pathology, International Crops Research Institute for the Semi-Arid Tropics, Patancheru 502 324, India.

Current address of G. K. Kishore: Legumes Pathology, International Crops Research Institute for the Semi-Arid Tropics, Patancheru 502 324, India.

Accepted for publication 23 May 2005.

\begin{abstract}
Kishore, G. K., Pande, S., and Podile, A. R. 2005. Biological control of late leaf spot of peanut (Arachis hypogaea) with chitinolytic bacteria. Phytopathology 95:1157-1165.

Late leaf spot (LLS), caused by Phaeoisariopsis personata, is a foliar disease of groundnut or peanut (Arachis hypogaea) with high economic and global importance. Antifungal and chitinolytic Bacillus circulans GRS 243 and Serratia marcescens GPS 5, selected among a collection of 393 peanut-associated bacteria, were applied as a prophylactic foliar spray and tested for control of LLS. Chitin-supplemented application of B. circulans GRS 243 and S. marcescens GPS 5 resulted in improved

supplemented application of GRS 243 and GPS 5 also resulted in improved and stable control of LLS in a repeated field experiment and increased the pod yields by 62 and $75 \%$, respectively, compared with the control. Chitin-supplemented application of GPS 5 was tested in six onfarm trials, and the increase in pod yields was up to $48 \%$ in kharif (rainy season). A 55-kDa chitinase was purified from the cell-free culture filtrate of GPS 5 by affinity chromatography and gel filtration. Purified chitinase of $S$. marcescens GPS 5 (specific activity 120 units) inhibited the in vitro germination of $P$. personata conidia, lysed the conidia, and effectively controlled LLS in greenhouse tests, indicating the importance of chitinolysis in biological control of LLS disease by GPS 5 .
\end{abstract} biological control of LLS disease. Supplementation of bacterial cells with $1 \%(\mathrm{wt} / \mathrm{vol})$ colloidal chitin reduced lesion frequency by $60 \%$ compared with application of bacterial cells alone, in the greenhouse. Chitin-
Additional keywords: biotrophic, phylloplane, rhizobacteria.
Biological control of fungal diseases of plants is eco-friendly and is a potential component of integrated disease management. Biological control of foliar diseases has received less attention, owing to the poor establishment of the introduced biocontrol agents and resulting variations in disease control. Biocontrol agents in the phylloplane are continuously subjected to rapid and extreme variations in moisture and temperature, exposure to ultraviolet radiation, and limited nutrient availability (5). Hence, the introduced antagonists lose their viability within a short duration and need to be reapplied frequently. Bacteria require a strategy of survival to tolerate direct exposure to UV radiation, low water availability, and other environmental stresses on leaf surfaces (2). Maintenance of threshold populations of the introduced biocontrol agents on the phylloplane has remained the focus of biocontrol research. Nutrient-supplemented application of biocontrol agents augments the rate and time of survival of the introduced biocontrol agent in the phylloplane. Chitin, a linear polymer of $\mathrm{N}$-acetyl glucosamine (NAG), is selectively degraded by the chitinolytic organisms and used as a carbon source for their growth and multiplication. Chitinolytic microorganisms can be applied with chitin for better survival of the introduced agents in the phylloplane to control fungal diseases. Chitin-supplemented application of Stenotrophomonas maltophilia C3 improved the control of bean rust (38) and leaf spot of Festuca arundinacea (40) compared with that of strain C3 alone. Chitin-supplemented application of chitinolytic bacteria has also been proved effective

Corresponding author: A. R. Podile; E-mail addresses: arpsl@uohyd.ernet.in or podilerao@yahoo.com

DOI: 10.1094/PHYTO-95-1157

(C) 2005 The American Phytopathological Society in control of other foliar diseases including early leaf spot of peanut (22) and soilborne diseases $(3,17)$. Phyllobacteria can modify their environment to enhance their colonization of plants by increasing local nutrient concentrations or by producing a layer of extracellular polysaccharides either on the surface of leaves or in the interior (2).

Parasitism of pathogenic fungi, facilitated by the production of hydrolytic enzymes, is involved in biological control of fungal diseases. Among the hydrolytic enzymes, chitinases are of prime importance since chitin is a major cell wall constituent in the majority of phytopathogenic fungi. Chitinases inhibit fungal spore germination and germ tube elongation (25), and lyse hyphal tips (29). Purified chitinases of Trichoderma harzianum (13), Gliocladium virens (11), Serratia marcescens (29), Serratia plymuthica (14), and Streptomyces sp. (16) were highly antifungal. The importance of chitinolysis in biological control of fungal diseases of plants was supported by several observations, namely increased disease control by chitin-supplemented application of chitinolytic biocontrol agents $(26,42)$, and greater field efficiency of chitinase preparations in disease control (32). Biocontrol strains that overexpress chitinase had increased antifungal activity (24), and mutant strains, deficient in chitinase production, exhibit reduced antifungal activity and disease control ability (42). Biocontrol efficacy of nonchitinolytic Pseudomonas fluorescens was enhanced by expression of the ChiA gene from $S$. marcescens (12).

Late leaf spot (LLS) disease, caused by Phaeoisariopsis personata (Berk. \& M.A. Curtis) Arx [=Cercosporidium personatum (Berk. \& M.A. Curtis) Deighton], is an economically important foliar disease and major yield-reducing factor of groundnut or peanut (Arachis hypogaea L.) in Asia and the Americas. Yield losses of $>50 \%$ were common due to LLS infection (28). Successful biological control of foliar diseases like LLS are scarce, 
and the bacterial strains registered as biofungicides for control of foliar diseases are not primarily dependent on chitinolytic ability. The present study was, therefore, an attempt to test the selected chitinolytic bacterial strains from a large collection of peanutassociated bacteria (native to the Indian subcontinent), as a foliar spray for the control of LLS, with and without chitin supplementation in both the controlled environment and the field. Further, the chitinolytic ability of $S$. marcescens GPS 5 was characterized to test the possibility of using bacterial chitinases for control of LLS.

\section{MATERIALS AND METHODS}

Microorganisms. A single lesion isolate of $P$. personata collected from field-grown plants with LLS was maintained on detached peanut leaves (35). Two bacterial isolates, Bacillus circulans GRS 243 and S. marcescens GPS 5, were selected for their chitinolytic and in vitro antifungal activity against $P$. personata from a collection of 393 peanut-associated bacteria (21). These two strains inhibited the conidial germination of $P$. personata by $>80 \%$ compared with the control. B. circulans GRS 243 was isolated from the rhizosphere of peanut and $S$. marcescens GPS 5 from peanut phylloplane.

Greenhouse testing of chitinolytic bacteria. Cells of B. circulans GRS 243 and S. marcescens GPS 5 harvested from mid-log phase cultures in Luria-Bertani (LB) broth and resuspended in $10 \mathrm{mM}$ phosphate buffer, $\mathrm{pH} 7.0$, at a concentration of $10^{8} \mathrm{CFU}$ $\mathrm{ml}^{-1}$, were applied as a foliar spray onto 30-day-old greenhousegrown peanut plants of cv. TMV 2. Foliar application of the biocontrol isolates was supplemented with colloidal chitin at concentrations of 0.2 to $1.0 \%(\mathrm{wt} / \mathrm{vol})$ in increments of $0.2 \%$. Foliar application with phosphate buffer alone and colloidal chitin suspension served as controls. After $24 \mathrm{~h}$, the plants were challenge-inoculated with a conidial suspension of $P$. personata $\left(2 \times 10^{4}\right.$ conidia $\left.\mathrm{ml}^{-1}\right)$ with an atomizer. Inoculated plants were incubated in alternate wet $(16 \mathrm{~h})$ and dry $(8 \mathrm{~h})$ periods of leaf wetness up to 8 days after inoculation (DAI) by shifting between the dew chambers (9) and greenhouse. Throughout the experiments, temperature was maintained at $24 \pm 2^{\circ} \mathrm{C}$. All 18 treatments consisted of 24 plants in three replications, with four plants in each pot, arranged in a completely randomized block design. Pathogen inoculation and experimental design remained the same for all the greenhouse experiments and were repeated twice.

Disease severity in different treatments was compared as (i) lesion frequency (LF, number of lesions per square centimeter of leaf area at 15 DAI), and (ii) disease score (DS) on a 1-to-9 rating scale (34) at 30 DAI. LF was scored on the third leaf from the top, tagged before pathogen inoculation. The details of the rating scale for disease scoring are as follows: $1=$ no disease; $2=$ few, small necrotic spots on lower and middle leaves; $3=$ small spots, mainly on lower and middle leaves, sparse sporulation; 4 = many spots, mostly on lower and middle leaves, disease evident; $5=$ spots easily seen on lower and middle leaves, moderately sporulating, yellowing and defoliation evident; $6=$ same as rating 5 but spots heavily sporulating; $7=$ spots present all over the plant, lower and middle leaves defoliating; $8=$ same as rating 7 but defoliation is more severe; and $9=$ plants severely affected, 50 to $100 \%$ defoliation.

Greenhouse testing of the cell-free culture filtrates. $\mathrm{B}$. $\mathrm{circu}$ lans GRS 243 and $S$. marcescens GPS 5 were grown in minimal medium with $1 \%$ colloidal chitin as the sole carbon source for $144 \mathrm{~h}$ at $30^{\circ} \mathrm{C}$ and $180 \mathrm{rpm}$. The cultures were centrifuged for $10 \mathrm{~min}$ at $10,000 \mathrm{rpm}$ and $4^{\circ} \mathrm{C}$. The supernatants were filtersterilized and applied as a foliar spray $24 \mathrm{~h}$ before $P$. personata inoculation for control of LLS. Sterile minimal medium was used as control. The three treatments consisted of 24 plants in three replications, and the experiment was repeated twice.
Greenhouse evaluation of peat-based formulations for control of LLS disease. Peat-based formulations of $B$. circulans GRS 243 and $S$. marcescens GPS 5 were prepared. The initial pH of the peat was 6.1 and it was adjusted to 7.0 by adding $\mathrm{CaCO}_{3}$. The formulations also were supplemented with $1 \%$ colloidal chitin. The carrier material was packed in individual high molecular and high density polyethylene bags, and sterilized by autoclaving at $121^{\circ} \mathrm{C}$ for $20 \mathrm{~min}$. Cells of GPS 5 and GRS 243 harvested from mid-log phase cultures in LB broth were resuspended in equal volume of $10 \mathrm{mM}$ phosphate buffer, $\mathrm{pH}$ 7.0. The cell suspension was diluted 100 -fold and aseptically added to the carrier material at $50 \%$ (vol/wt). Uniform adsorption of the inoculum into the carrier material was ensured and incubated at $30^{\circ} \mathrm{C}$. Moisture loss of the formulations was compensated by the addition of sterile distilled water at regular intervals. Viability of bacteria in the carrier material was determined at regular intervals up to 180 DAI by dilution plating and determining log CFU per gram. Each treatment was replicated four times, and the experiment was repeated twice.

For greenhouse evaluation of the formulations of B. circulans GRS 243 and S. marcescens GPS 5 for LLS disease control, 90-day-old formulations were suspended in $10 \mathrm{mM}$ phosphate

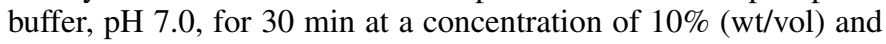
filtered through cheesecloth. The filtrate was applied as a foliar spray $24 \mathrm{~h}$ before $P$. personata inoculation with sterile peat filtrate as the control. The treated plants were maintained in the greenhouse as described previously. Control of LLS disease with peatbased formulations, with or without chitin, was compared with disease control with fresh cells of GRS 243 and GPS 5. The experiment was repeated twice with three replications and eight plants in each replication.

Field evaluation of the biocontrol isolates for LLS control. Field evaluation of $B$. circulans GRS 243 and S. marcescens GPS 5 for LLS control was conducted at the International Crops Research Institute for the Semi-Arid Tropics (ICRISAT), Patancheru, during 2001 and 2002 rainy seasons (July to October). In each treatment, LLS susceptible cv. TMV 2 was planted in four rows of 9-m length with an intra- and inter-row spacing of 15 and $60 \mathrm{~cm}$, respectively. After every four test rows, one row of cv. TMV 2 was planted that was inoculated with $P$. personata and received no other treatment. The inoculated rows served to increase inoculum pressure on adjacent treatment rows and maintain uniform disease development throughout the experimental plots. Three replications of each treatment were arranged in a completely randomized block design. $P$. personata inoculation and subsequent maintenance of leaf wetness required for disease development were conducted according to the method of Subrahmanyam et al. (36). The following treatments applied as a foliar spray at 45, 60, 75, and 90 days after sowing (DAS) at 500 liters $\mathrm{ha}^{-1}$ were evaluated for LLS control: (i) GRS 243 $\left(10^{8} \mathrm{CFU} \mathrm{ml} \mathrm{ml}^{-1}\right)$ suspended in phosphate buffer, (ii) GPS 5 $\left(10^{8} \mathrm{CFU} \mathrm{m \textrm {m } ^ { - 1 }}\right)$ suspended in phosphate buffer, (iii) cell suspension GRS 243 supplemented with $1 \%$ colloidal chitin, (iv) cell suspension GPS 5 supplemented with $1 \%$ colloidal chitin, (v) $1 \%$ colloidal chitin, (vi) chlorothalonil $(0.2 \%)$, and (vii) $10 \mathrm{mM}$ phosphate buffer, $\mathrm{pH}$ 7.0.

Quantification of disease severity at 10-day intervals, starting at 45 DAS until harvest, was determined using the 1-to-9 rating scale (34) described earlier. After harvest, the pods were sun-dried and yield in each treatment was calculated per hectare.

Phylloplane survival of the bacterial isolates. Survival and multiplication of $B$. circulans GRS 243 and $S$. marcescens GPS 5 in the peanut phylloplane was determined by using rifampicin resistance as a marker. Spontaneous mutants of rifampicinsensitive bacterial isolates, GRS $243-\mathrm{R}_{1}$ and GPS $5-\mathrm{R}_{1}$, were obtained by plating the cell suspension $\left(\approx 10^{9} \mathrm{CFU} \mathrm{ml}{ }^{-1}\right)$ on nutrient agar amended with 50 and $100 \mu \mathrm{g} \mathrm{ml}^{-1}$ rifampicin, respectively. The mutants observed after an incubation of $96 \mathrm{~h}$ at $30^{\circ} \mathrm{C}$ were 
checked for stability of rifampicin resistance by subculturing the mutants 20 times on nutrient agar medium with $100 \mu \mathrm{g} \mathrm{ml}^{-1}$ rifampicin.

In the field, at 60 DAS, GRS $243-\mathrm{R}_{1}$ and GPS 5-R $\left(10^{8} \mathrm{CFU}\right.$ $\mathrm{ml}^{-1}$ ) were applied as a foliar spray with and without $1 \%$ colloidal chitin supplementation. To determine the populations of rifampicin-resistant GRS 243- $R_{1}$ and GPS 5- $R_{1}$ at 24-h intervals, four randomly selected leaflets from different plants were excised and

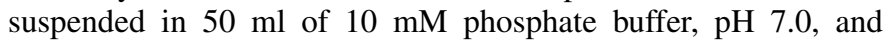
incubated for $1 \mathrm{~h}$ at $180 \mathrm{rpm}$ and $30^{\circ} \mathrm{C}$. Leaves from plants without any bacterial spray served as controls. Serial dilutions were plated on nutrient agar amended with $100 \mu \mathrm{g} \mathrm{ml}^{-1}$ rifampicin, and populations observed after $48 \mathrm{~h}$ were expressed as log CFU per gram of leaf. The observations were based on three plates in each dilution, and the experiment was repeated with three replications.

On-farm evaluation of $S$. marcescens GPS 5. Farmers' participatory on-farm trials were conducted to evaluate $S$. marcescens GPS 5 as a biocontrol agent of LLS in two districts of Andhra Pradesh, India. The trials were conducted in three fields at Ghattikal village, Nalgonda district in kharif 2003 (rainy season; July to October), and repeated at Ippakunta village, Mahaboobnagar district in rabi 2003 (post-rainy season; December to April).

The peanut genotype used in these experiments was the local cultivar traditionally adopted by farmers and is highly susceptible to LLS. In the kharif 2003 field trials, each treatment consisted of six rows of $10-\mathrm{m}$ length, and in rabi 2003, a 50- $\mathrm{m}^{2}$ plot was maintained in each treatment because the planting was not in rows. Each treatment was replicated three times in a completely randomized block design. The bacterial cells were resuspended in water just before their application. The following different treatments were applied as a foliar spray: (i) mid-log phase cells of GPS 5, (ii) mid-log phase cells of GPS 5 supplemented with $1 \%$ (wt/vol) colloidal chitin, (iii) chlorothalonil $(0.2 \%$, wt/vol), and (iv) water. Isolate GPS 5 and chlorothalonil were applied as a foliar spray, whereas chitin-supplemented GPS 5 was sprinkled onto the plants three times during the crop season. At kharif, the treatments were applied at 55, 70, and 85 DAS, and in rabi at 75, 90 , and 105 DAS because of poor plant growth during the winter season followed by the delayed initiation of LLS. Severity of LLS was recorded on a 1-to-9 rating scale (34) at regular intervals starting from disease initiation until harvest.

Partial characterization of chitinase(s) of $S$. marcescens GPS 5. Chitinase assay. A chitinase assay was performed using colloidal chitin as a substrate (6). One unit of enzyme activity was defined as micromoles of NAG released per milliliter per hour. The specific activity was expressed as units of enzyme activity per milligram of protein, where the protein concentration was determined as described by Bradford (7).

Purification of chitinase. S. marcescens GPS 5 was grown in minimal medium with colloidal chitin as a carbon source for 8 days at $30^{\circ} \mathrm{C}$ and $180 \mathrm{rpm}$. Five hundred milliliters of the culture was centrifuged at $10,000 \mathrm{rpm}$ for $10 \mathrm{~min}$, and the supernatant was filter-sterilized. Proteins in the clear supernatant were pelleted by adding $\left(\mathrm{NH}_{4}\right)_{2} \mathrm{SO}_{4}$ to $100 \%$ saturation, and the pellet was dissolved in a minimal volume of $1 \times$ phosphate-buffered saline and dialyzed against the same.

Affinity chromatography. About $30 \mathrm{~g}$ of powdered chitin was suspended in 1 liter of $1 \mathrm{~N} \mathrm{HCl}$ and allowed to swell at $4{ }^{\circ} \mathrm{C}$ for $16 \mathrm{~h}$. The swollen chitin was washed extensively with deionized water to bring to a neutral $\mathrm{pH}$. Finally, the chitin was washed with $20 \mathrm{mM}$ sodium acetate buffer, $\mathrm{pH} 5.8$, packed into a column (10 by $2.5 \mathrm{~cm}$ ) at $4{ }^{\circ} \mathrm{C}$, and equilibrated with the same buffer.

The dialyzed proteins were loaded onto the chitin column at $10 \mathrm{mg}$ of protein $\mathrm{g}^{-1}$ matrix, and the flow rate was adjusted to $15 \mathrm{ml} \mathrm{h}^{-1}$. The flow through was re-applied on the column to ensure complete binding of chitin-binding proteins to the matrix. The unbound proteins were eluted using $100 \mathrm{mM}$ sodium acetate buffer, $\mathrm{pH}$ 5.8. The chitin-binding proteins were eluted in two steps using $100 \mathrm{mM}$ sodium acetate buffer at $\mathrm{pH} 4.8$ and $\mathrm{pH}$ 3.6. One-milliliter fractions with maximum protein concentration were analyzed for chitinase activity by colorimetry and purity by sodium dodecyl sulfate-polyacrylamide gel electrophoresis (SDSPAGE) (23).

Detection of enzymatic activity after SDS-PAGE. Chitinase activity of SDS-PAGE separated proteins was confirmed using glycol chitin as a substrate followed by Calcofluor white M2R staining (37).

Gel filtration. Ten grams of Sephadex G 100 soaked for $24 \mathrm{~h}$ in $500 \mathrm{ml}$ of $20 \mathrm{mM}$ Tris- $\mathrm{HCl}$ buffer, $\mathrm{pH} \mathrm{7.0,} \mathrm{was} \mathrm{packed} \mathrm{into} \mathrm{a}$ column $(75$ by $1.5 \mathrm{~cm})$, and the flow rate was adjusted at $15 \mathrm{ml} \mathrm{h}^{-1}$. The column was washed extensively with deionized water followed by $100 \mathrm{mM}$ sodium acetate buffer, $\mathrm{pH}$ 5.8. Chitin-binding proteins eluted from the affinity column were pooled, concentrated, suspended in 1-ml volumes of sodium acetate buffer, $\mathrm{pH}$ 5.8, and loaded onto the Sephadex column and eluted with the same buffer. Standard molecular weight protein markers (blue dextran 2,000 kDa, albumin $66 \mathrm{kDa}$, ovalbumin $43 \mathrm{kDa}$, chymotrypsinogen A $25 \mathrm{kDa}$, and ribonuclease A $13.2 \mathrm{kDa}$ ) dissolved in $1.0 \mathrm{ml}$ of $20 \mathrm{mM}$ Tris- $\mathrm{HCl}, \mathrm{pH} \mathrm{7.0,}$, also were loaded onto the column. Fractions with maximum protein concentration were analyzed for enzyme activity by colorimetry and purity by SDSPAGE. The elution profile of protein standards was plotted to determine the molecular weight of the eluted proteins.

Antifungal activity of $\boldsymbol{S}$. marcescens GPS 5 chitinase. The $55-\mathrm{kDa}$ purified chitinase of $S$. marcescens GPS 5 was tested for inhibition of in vitro germination of conidia of $P$. personata. Equal volumes $(25 \mu \mathrm{l})$ of the conidial suspension $\left(10^{5}\right.$ conidia $\left.\mathrm{ml}^{-1}\right)$ and enzyme in $10 \mathrm{mM}$ phosphate buffer, $\mathrm{pH} 7.0$ (final concentrations of $10,20,25,30,35$, and $40 \mu \mathrm{g} \mathrm{ml}^{-1}$ ), were mixed on a cavity slide. The slides were incubated in a humid chamber in darkness at $28^{\circ} \mathrm{C}$ and conidial germination was observed under a light microscope after $24 \mathrm{~h}$.

Greenhouse evaluation of chitinase for control of LLS. The purified $55-\mathrm{kDa}$ chitinase $\left(35 \mu \mathrm{g} \mathrm{ml}^{-1}\right.$ ) of $S$. marcescens GPS 5 was applied as a foliar spray, $24 \mathrm{~h}$ before pathogen inoculation, for control of LLS in the greenhouse. Plants sprayed with $10 \mathrm{mM}$ phosphate buffer, $\mathrm{pH}$ 7.0, served as the control. The experiment was conducted twice in triplicate treatments with four plants in each replication.

Data analysis. The data of greenhouse and field experiments were subjected to analysis of variance (ANOVA) using the Genstat 5 statistical package (Lawes Agricultural Trust, Rothamsted Experimental Station, Harpenden, Hertfordshire, UK). Data values of bacterial survival in the formulations and in the phylloplane were log-transformed before subjecting to ANOVA. The mean values in each treatment were compared with an $F$ protected LSD at $P=0.05$ or $P=0.01$. In the repeated field experiments, disease severity and pod yields of different treatments were not significantly different between the two crop seasons; therefore, data were pooled and analyzed.

\section{RESULTS}

Greenhouse testing of chitinolytic bacteria. Foliar application of $B$. circulans GRS 243 and $S$. marcescens GPS 5 significantly $(P<0.001)$ reduced the LF by 21 and $18 \%$, respectively, compared with that of the phosphate buffer control (Table 1). Chitin-supplemented application of GRS 243 and GPS 5 significantly $(P<0.001)$ reduced LF compared with that of the bacterial cells alone. Foliar application of chitin was not different from phosphate buffer against LLS. With an increase of colloidal chitin concentration up to $1.0 \%$ (wt/vol), the decrease in LF and DS was significant $(P<0.001)$ in the presence of GRS 243 and GPS 5. Application of GRS 243 and GPS 5 reduced LF by 62 and $63 \%$, respectively, when supplemented with $1 \%$ colloidal chitin. At 30 DAI, plants treated with $1 \%$ chitin-supplemented GRS 243 
and GPS 5 had a disease severity of 4.2 and 3.8 on a 1-to- 9 rating scale compared with 9.0 in the control.

Greenhouse testing of the cell-free culture filtrates. Cell-free culture filtrates of $B$. circulans GRS 243 and $S$. marcescens GPS 5 grown in minimal medium with colloidal chitin as a carbon source reduced LF $(P<0.001)$ by 56 and $58 \%$, respectively, compared with the control (Fig. 1).

Greenhouse evaluation of peat-based formulations for control of LLS disease. In peat formulation, B. circulans GRS 243 had a shelf-life $\left(\log 7.4 \mathrm{CFU} \mathrm{g}^{-1}\right.$ ) of at least $180 \mathrm{DAI}$, whereas S. marcescens GPS 5 was not detectable 120 DAI (Fig. 2). Chitin supplementation significantly improved the shelf-life of both isolates. In the presence of chitin, populations of GRS 243 increased from $\log 7.1$ to $\log 9.0 \mathrm{CFU} \mathrm{\textrm {g } ^ { - 1 }}$, and for GPS 5 from $\log 6.9$ to $\log 9.1$ CFU g ${ }^{-1}$.

Chitin-supplemented peat formulations of $B$. circulans GRS 243 and $S$. marcescens GPS 5 reduced LF by 58 and $54 \%$ compared with the control, while peat formulations of GRS 243 reduced LF by $25 \%$ (Table 2 ). These treatments were significantly $(P<0.001)$ different from the control, while peat formulations of GPS 5 were not different from the control. Actively growing cells of GPS 5 applied to leaves proved more effective compared with peat formulations and less effective than the chitin-supplemented peat formulations for the control of LLS disease in the greenhouse.

Field evaluation of the biocontrol isolates for LLS control. In both crop seasons, LLS severity in B. circulans GRS 243 and $S$. marcescens GPS 5 treatments was not significantly $(P=0.05)$ different from the control (Fig. 3A and B). Chitin-supplemented

TABLE 1. Effect of chitin-supplemented application of chitinolytic bacterial isolates on the development of late leaf spot in peanut

\begin{tabular}{lccc}
\hline Isolate & $\begin{array}{c}\text { Colloidal chitin } \\
(\%, \mathrm{wt} / \mathrm{vol})^{\mathrm{a}}\end{array}$ & $\begin{array}{c}\text { Lesion } \\
\text { frequency }\end{array}$ & $\begin{array}{c}\text { Disease } \\
\text { score }^{\mathrm{c}}\end{array}$ \\
\hline Bacillus circulans GRS 243 & 0.0 & $2.86 \pm 0.39^{\mathrm{d}}$ & $8.0 \pm 0.5$ \\
B. circulans GRS 243 & 0.2 & $2.79 \pm 0.29$ & $7.6 \pm 0.4$ \\
B. circulans GRS 243 & 0.4 & $2.50 \pm 0.3$ & $7.2 \pm 0.5$ \\
B. circulans GRS 243 & 0.6 & $1.92 \pm 0.15$ & $6.6 \pm 0.6$ \\
B. circulans GRS 243 & 0.8 & $1.21 \pm 0.14$ & $5.0 \pm 0.5$ \\
B. circulans GRS 243 & 1.0 & $1.09 \pm 0.12$ & $4.2 \pm 0.6$ \\
Serratia marcescens GPS 5 & 0.0 & $2.95 \pm 0.17$ & $8.0 \pm 0.3$ \\
S. marcescens GPS 5 & 0.2 & $2.73 \pm 0.34$ & $7.8 \pm 0.5$ \\
S. marcescens GPS 5 & 0.4 & $2.30 \pm 0.41$ & $7.4 \pm 0.5$ \\
S. marcescens GPS 5 & 0.6 & $1.41 \pm 0.21$ & $5.8 \pm 0.6$ \\
S. marcescens GPS 5 & 0.8 & $1.19 \pm 0.17$ & $4.4 \pm 0.6$ \\
S. marcescens GPS 5 & 1.0 & $1.08 \pm 0.13$ & $3.8 \pm 0.5$ \\
Control & 0.0 & $3.60 \pm 0.51$ & $9.0 \pm 0$ \\
Control & 0.2 & $3.64 \pm 0.4$ & $9.0 \pm 0$ \\
Control & 0.4 & $3.58 \pm 0.37$ & $9.0 \pm 0$ \\
Control & 0.6 & $3.55 \pm 0.42$ & $9.0 \pm 0$ \\
Control & 0.8 & $3.51 \pm 0.31$ & $9.0 \pm 0$ \\
Control & 1.0 & $3.45 \pm 0.43$ & $9.0 \pm 0$ \\
LSD $(P=0.01)$ & & & \\
Isolate & & 0.11 & 0.14 \\
Colloidal chitin & & 0.16 & 0.20 \\
Isolate $\times$ colloidal chitin & & 0.27 & 0.35 \\
\hline
\end{tabular}

${ }^{a}$ Foliar application of bacterial cells suspended in $10 \mathrm{mM}$ phosphate buffer, $\mathrm{pH} 7.0\left(10^{8} \mathrm{CFU} \mathrm{m}{ }^{-1}\right)$ was supplemented with different concentrations of colloidal chitin.

${ }^{\mathrm{b}}$ Lesion frequency (number of lesions per square centimeter of leaf area) was measured 15 days after inoculation.

${ }^{\mathrm{c}}$ Disease score on a 1-to-9 rating scale (34) was measured 30 days after inoculation where $1=$ no disease $; 2$ few, small necrotic spots on lower and middle leaves; $3=$ small spots, mainly on lower and middle leaves, sparse sporulation; 4 = many spots, mostly on lower and middle leaves, disease evident; $5=$ spots easily seen on lower and middle leaves, moderately sporulating, yellowing and defoliation evident; $6=$ same as rating 5 but spots heavily sporulating; $7=$ spots present all over the plant, lower and middle leaves defoliating; $8=$ same as rating 7 but defoliation is more severe; and $9=$ plants severely affected, 50 to $100 \%$ defoliation.

${ }^{\mathrm{d}}$ Data points are the mean of nine replications from three sets of experiments. $\pm=$ standard error of the mean. application of these two isolates resulted in improved control of LLS. The effect of chitin-supplemented application of GRS 243 and GPS 5 on the severity of LLS was not different from chlorothalonil until 85 DAS. In these two treatments the severity of LLS at 95 DAS was 4.7 and 4.3, respectively, compared with 9.0 in the control and 3.0 in the chlorothalonil treatment.

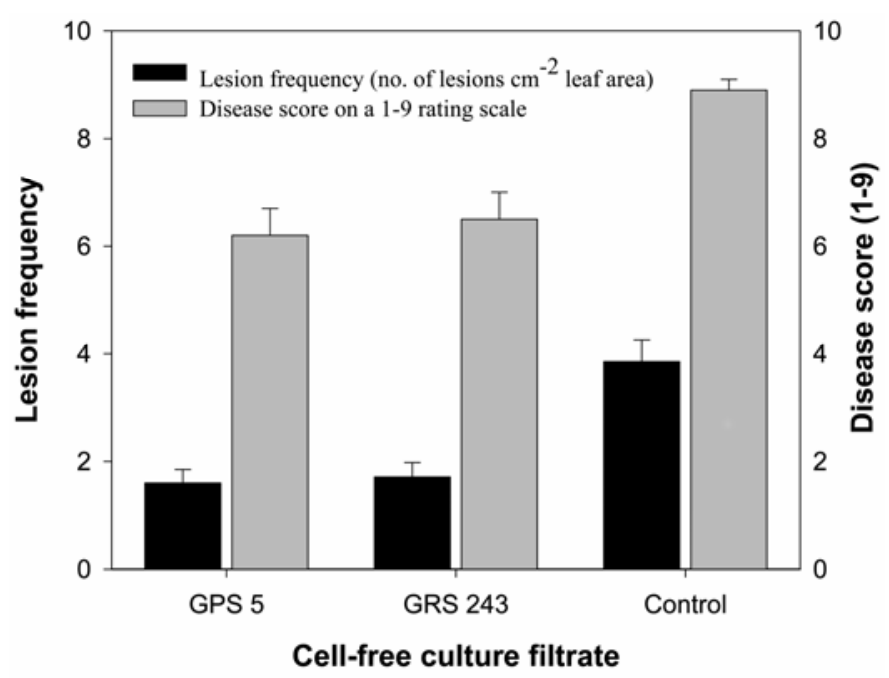

Fig. 1. Effect of cell-free culture filtrates of chitinolytic Bacillus circulans GRS 243 and Serratia marcescens GPS 5 on the development of late leaf spot of peanut in the greenhouse. Lesion frequency was measured as number of lesions per square centimeter of leaf area. Disease score was on a 1-to-9 rating scale (34) in which 1 = no disease; 2 = few, small necrotic spots on lower and middle leaves; 3 = small spots, mainly on lower and middle leaves, sparse sporulation; 4 = many spots, mostly on lower and middle leaves, disease evident; 5 = spots easily seen on lower and middle leaves, moderately sporulating, yellowing, and defoliation evident; $6=$ same as rating 5 but spots heavily sporulating; $7=$ spots present all over the plant, lower and middle leaves defoliating; $8=$ same as rating 7 but defoliation is more severe; and $9=$ plants severely affected, 50 to $100 \%$ defoliation measured at 15 and 30 days after pathogen inoculation. Data points are the mean of nine replications; three replicates from three experiments were pooled. The vertical bars of each data point represent the standard error of the mean.

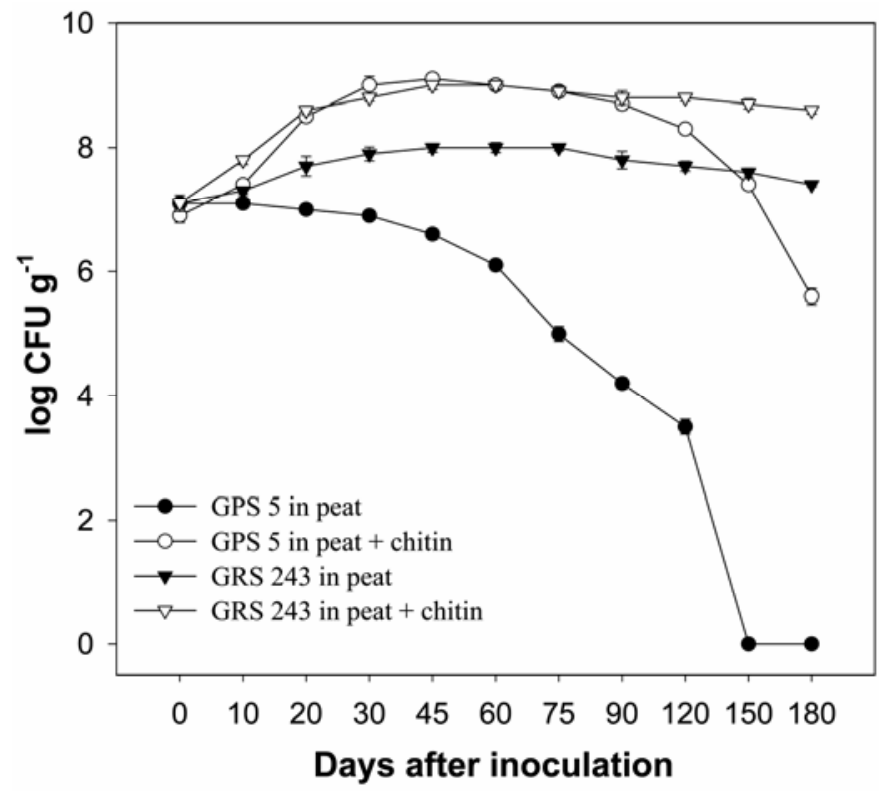

Fig. 2. Survival of chitinolytic Bacillus circulans GRS 243 and Serratia marcescens GPS 5 in peat-based formulations. For chitin supplementation, $1 \%$ (wt/vol) colloidal chitin was added to neutralized peat. Data points are the mean of 12 replications in three sets of experiments (four replicates per experiment). The vertical bars of each data point represent the standard error of the mean. 
B. circulans GRS 243 and $S$. marcescens GPS 5 applied without chitin supplementation had no effect on the pod yield of peanut. Chitin-supplemented application of these two isolates resulted in an increase of 62 and $75 \%$ in pod yield. Maximum pod yield of 1.11 tonne $\mathrm{ha}^{-1}$ (102\% higher than control) was obtained with the chlorothalonil treatment (Table 3).

Phylloplane survival of the bacterial isolates. Chitin supplementation enhanced the phylloplane survival of rifampicin-resistant mutants of B. circulans GRS 243 and $S$. marcescens GPS 5 by $>10$-fold (Fig. 4). At 7 DAI, the populations of GRS $243-R_{1}$ and GPS 5-R $\mathrm{R}_{1}$ applied with chitin supplementation were $\log 4.6$ and 4.2 CFU g ${ }^{-1}$ leaf in comparison to $\log 3.5$ and 3.0 $\mathrm{CFU} \mathrm{g}^{-1}$, respectively, when the bacterial cells were applied alone.

On-farm evaluation of $\boldsymbol{S}$. marcescens GPS 5. In kharif 2003 (Fig. 5, trials I to III), the incidence of Spodoptera litura (tobacco caterpillar) was severe up to $60 \mathrm{DAS}$, due to the prevalent conducive rainfall and low temperature. Symptoms of LLS were observed 50 DAS, in only one of the three trials, where the vegetative growth was in excess and the canopy was dense. The disease progress was rapid from 65 DAS in all the trials. Chlorothalonil was highly effective for control of LLS followed by chitin-supplemented application of GPS 5; GPS 5 alone was not effective. Chitin-supplemented application of GPS 5 was comparable $(P<0.05)$ to chlorothalonil from 55 to 85 DAS in most trials. The disease severity in this treatment in two of the trials (trials I and III) at harvest was 4.7 and 5.3 compared with 7.3 and 8.0 in the control (Fig. 5). In the other trial (trial II), the crop was harvested early at 85 DAS to avoid terminal drought. At this time the disease severity in plants treated with chitin-supplemented GPS 5 was 4.7 compared with 6.7 in the control. The pod yield per plant determined in two trials was highest with the chlorothalonil treatment $\left(22.4 \pm 0.9\right.$ and $\left.20.9 \pm 1.1 \mathrm{~g} \mathrm{plant}^{-1}\right)$ followed by chitin-supplemented application of GPS 5 (20.3 \pm 1.1 and $19.1 \pm$ $1.0 \mathrm{~g} \mathrm{plant}^{-1}$ ) compared with $13.8 \pm 1.1$ and $12.9 \pm 0.8 \mathrm{~g} \mathrm{plant}^{-1}$ in the control.

During 2003 rabi (Fig. 5, trials IV to VI), chlorothalonil was most effective among all the treatments, closely followed by the chitin-supplemented application of GPS 5. In trials IV and V, the pod yield with chitin-supplemented application of GPS 5 was

TABLE 2. Greenhouse evaluation of peat-based formulations of chitinolytic isolates for control of late leaf spot of peanut

\begin{tabular}{llll}
\hline Isolate & \multicolumn{1}{c}{ Formulation $^{\mathrm{a}}$} & $\begin{array}{c}\text { Lesion } \\
\text { frequency }^{\mathrm{b}}\end{array}$ & $\begin{array}{c}\text { Disease } \\
\text { score }^{\mathrm{c}}\end{array}$ \\
\hline $\begin{array}{l}\text { Bacillus circulans GRS 243 } \\
\text { B. circulans GRS 243 }\end{array}$ & $\begin{array}{l}\text { Mid-log phase cells } \\
\text { Peat formulation }\end{array}$ & $2.81 \pm 0.31^{\mathrm{d}}$ & $9.0 \pm 0.0$ \\
B. circulans GRS 243 & $\begin{array}{c}\text { Chitin-supplemented } \\
\text { peat formulation }\end{array}$ & $1.63 \pm 0.27$ & $9.0 \pm 0.0$ \\
Serratia marcescens GPS 5 & Mid-log phase cells & $2.73 \pm 0.23$ & $6.0 \pm 0.4$ \\
S. marcescens GPS 5 & Peat formulation & $3.71 \pm 0.18$ & $9.0 \pm 0.3$ \\
S. marcescens GPS 5 & Chitin-supplemented & & \\
Control & peat formulation & $1.78 \pm 0.12$ & $6.2 \pm 0.4$ \\
LSD $(P=0.01)$ & Sterile peat & $3.89 \pm 0.24$ & $9.0 \pm 0.0$ \\
\hline
\end{tabular}

${ }^{a}$ Ninety-day-old formulations were suspended in $10 \mathrm{mM}$ phosphate buffer, $\mathrm{pH} 7.0(10 \%, \mathrm{wt} / \mathrm{vol})$. The filtrate was applied as a foliar spray $24 \mathrm{~h}$ before pathogen inoculation.

${ }^{\mathrm{b}}$ Lesion frequency (number of lesions per square centimeter of leaf area) was measured 15 days after inoculation.

${ }^{c}$ Disease score on a 1-to-9 rating scale (34) was measured 30 days after inoculation $(1=$ no disease; 2 few, small necrotic spots on lower and middle leaves; $3=$ small spots, mainly on lower and middle leaves, sparse sporulation; 4 = many spots, mostly on lower and middle leaves, disease evident; $5=$ spots easily seen on lower and middle leaves, moderately sporulating, yellowing, and defoliation evident; $6=$ same as rating 5 but spots heavily sporulating; 7 = spots present all over the plant; lower and middle leaves defoliating; $8=$ same as rating 7 but defoliation is more severe; and $9=$ plants severely affected, 50 to $100 \%$ defoliation).

${ }^{\mathrm{d}}$ Data points are the mean of nine replications from three sets of experiments. $\pm=$ standard error of the mean.

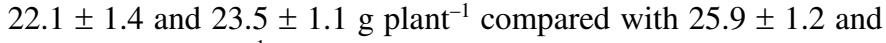
$28.1 \pm 1.7 \mathrm{~g} \mathrm{plant}^{-1}$ with chlorothalonil and $18.1 \pm 1.5$ and $19.0 \pm$ $0.9 \mathrm{~g} \mathrm{plant}^{-1}$ in the control. In one of the experimental fields (trial VI), disease progress was slow because of poor plant growth and density. In this field, both chlorothalonil and chitin-supplemented application of GPS 5 remained equally effective at 120 DAS.

Purification of chitinase(s) of $S$. marcescens GPS 5. Affinity chromatography. Two protein fractions were eluted with $100 \mathrm{mM}$ sodium acetate buffer, $\mathrm{pH} 4.8$ and 3.6. The two prominent peaks contained $21-$ and $55-\mathrm{kDa}$ proteins. The $55-\mathrm{kDa}$ protein had 102.3 units of chitinase activity and contained $26.2 \%$ of the total

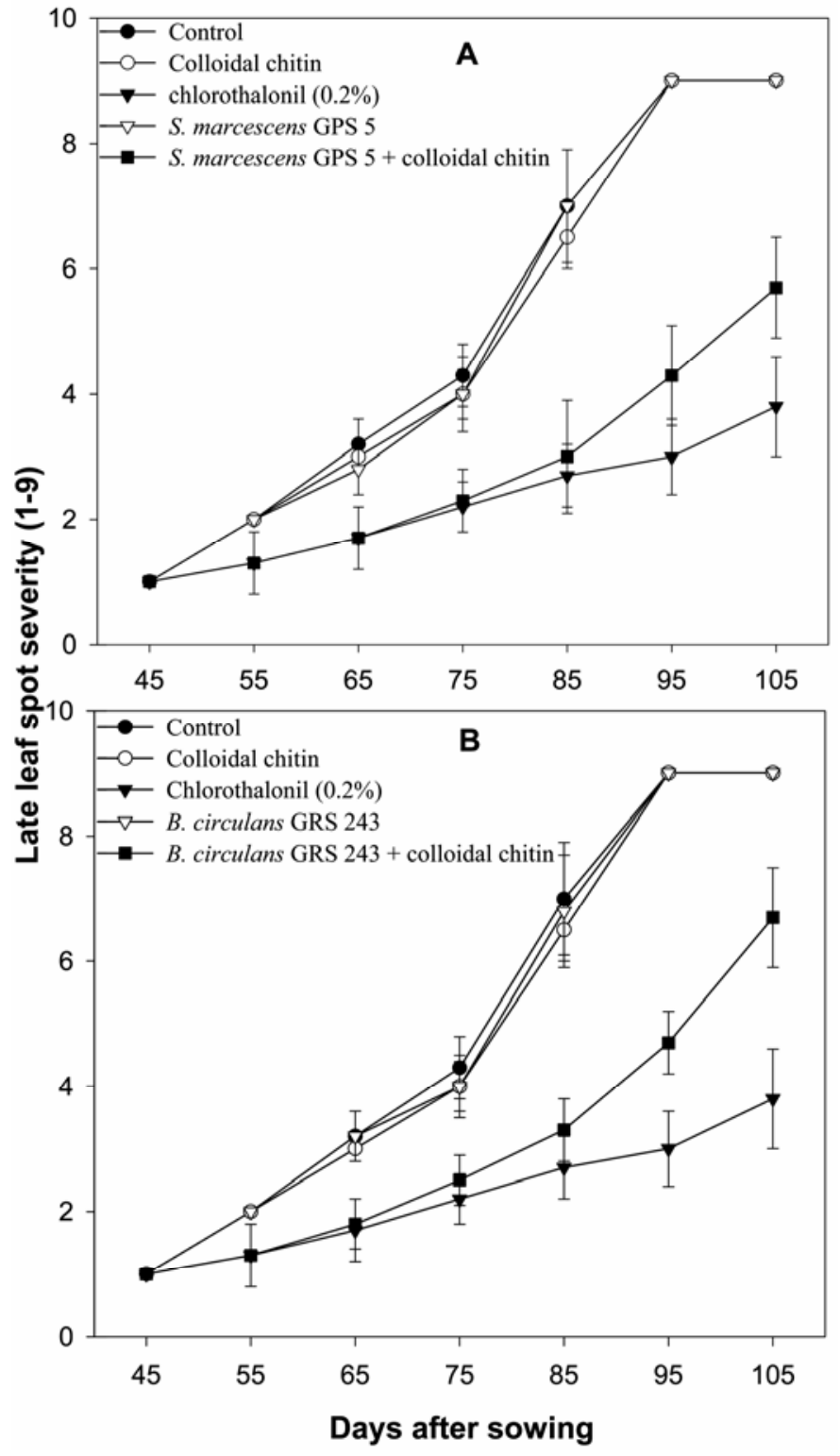

Fig. 3. Field evaluation of A, Serratia marcescens GPS 5 and B, Bacillus circulans GRS 243 with supplemented colloidal chitin $(1 \%$, wt/vol) for control of late leaf spot of peanut. Treatments were applied as foliar sprays at $45,60,75$, and 90 days after sowing. Disease score was measured on a 1-to-9 rating scale (34). $(1=$ no disease; $2=$ few, small necrotic spots on lower leaves; 3 = small spots, mainly on lower leaves, sparse sporulation; 4 = many spots, mostly on lower and middle leaves, disease evident; $5=$ spots easily seen on lower and middle leaves, moderately sporulating, yellowing and defoliation of some lower leaves; $6=$ same as rating 5 but spots heavily sporulating; 7 = disease easily seen from a distance, spots present all over the plant, and lower and middle leaves defoliating; $8=$ same as rating 7 but defoliation is more severe; and $9=$ plants severely affected, 50 to $100 \%$ defoliation.) Data points are the mean values of six replications from a repeated field experiment. The vertical bars of each data point represent the standard error of the mean. 
activity (Table 4). In both peaks, the proteins were co-eluted with trace amounts of contaminating protein. Hence, the fractions were pooled and further separated on a Sephadex G 100 column.

Gel filtration. Two proteins were eluted through Sephadex G 100 and had molecular weights of $\approx 42$ and $55 \mathrm{kDa}$. The protein that eluted near the $42-\mathrm{kDa}$ range resolved as a $21-\mathrm{kDa}$ dimeric protein on a $10 \%$ denaturing polyacrylamide gel. The $55-\mathrm{kDa}$ protein had a similar molecular weight both on native and denaturing polyacrylamide gels. When analyzed for enzymatic activity, the 21-kDa protein did not have chitinase activity, whereas the $55-\mathrm{kDa}$ protein had high enzyme activity. This protein fraction had a specific activity of 120.1 units and retained $22.8 \%$ of the total enzymatic activity (Table 4).

Detection of enzymatic activity after SDS-PAGE. The protein fractions eluted from the gel filtration column were checked for purity using SDS-PAGE. Individual bands of separated proteins were further tested for their enzymatic activity using glycol chitin as a substrate and Calcofluor white staining. The $55-\mathrm{kDa}$ protein had a clear zone of lysis of glycol chitin, whereas the $21-\mathrm{kDa}$ band had no such activity.

Antifungal activity of $S$. marcescens GPS 5 chitinase. Chitinase $\left(55-\mathrm{kDa}\right.$ protein) at a concentration of $10 \mu \mathrm{g} \mathrm{ml}^{-1}$ was significantly $(P<0.001)$ inhibitory $(60.3 \%)$ to the in vitro germination of $P$. personata conidia and the inhibitory action increased with enzyme concentration. The inhibition was maximum (94.6\%) at $35 \mu \mathrm{g} \mathrm{ml}^{-1}$ and the conidia were lysed.

Greenhouse evaluation of chitinase for control of LLS. Foliar application of chitinase at $35 \mu \mathrm{g} \mathrm{m}^{-1}, 24 \mathrm{~h}$ before pathogen inoculation, reduced LLS severity $(P<0.001)$. The LF measured in this treatment (1.42 lesions $\mathrm{cm}^{-2}$ of leaf area) was $59.7 \%$ less in comparison to the control (3.53 lesions $\mathrm{cm}^{-2}$ of leaf area). At 30 DAI, the disease severity in chitinase-treated plants was 4.6 on a 1-to-9 rating scale compared with 9.0 in control plants.

\section{DISCUSSION}

Chitin-supplemented application of B. circulans GRS 243 and S. marcescens GPS 5 resulted in improved control of LLS compared with application of bacterial cells alone. Both these strains are chitinolytic and inhibited the germination of conidia of Cercospora arachidicola, $P$. personata, and urediniospores of Puccinia arachidis (19). In a controlled environment, GRS 243 and GPS 5 significantly reduced LF compared with the control. Chitin supplementation further improved the efficacy of these strains and reduced LLS severity to higher levels and for prolonged periods, whereas foliar application of chitin had no effect on disease severity. Improved disease control by the two chitinolytic strains in the presence of chitin could be due to the increase in their populations by $>\log 1.0 \mathrm{CFU} \mathrm{g}^{-1}$ of leaf. Addi-

TABLE 3. Effect of colloidal chitin supplementation on the efficacy of chitinolytic isolates applied as a foliar spray for control of late leaf spot of peanut in terms of pod yield

\begin{tabular}{llc}
\hline Bacterial isolate $^{\mathrm{a}}$ & Foliar supplementation & $\begin{array}{c}\text { Pod yield } \\
\left(\text { tonnes }^{-1}\right)^{\mathrm{b}}\end{array}$ \\
\hline Bacillus circulans GRS 243 & - & $0.55 \pm 0.03$ \\
B. circulans GRS 243 & Colloidal chitin (1\%, wt/vol) & $0.89 \pm 0.07$ \\
Serratia marcescens GPS 5 & - & $0.53 \pm 0.05$ \\
S. marcescens GPS 5 & Colloidal chitin (1\%, wt/vol) & $0.96 \pm 0.06$ \\
Colloidal chitin (1\%, wt/vol) & - & $0.57 \pm 0.04$ \\
Chlorothalonil $(0.2 \%, \mathrm{wt} / \mathrm{vol})$ & - & $1.11 \pm 0.06$ \\
Control & - & $0.55 \pm 0.03$ \\
LSD $(P=0.01)$ & - & 0.16 \\
\hline
\end{tabular}

${ }^{a}$ Bacterial cells from mid-log phase cultures were resuspended in phosphate buffer, $\mathrm{pH} 7.0\left(10^{8} \mathrm{CFU} \mathrm{ml^{-1 }}\right)$ and applied as a foliar spray at $45,60,75$, and 90 days after sowing.

${ }^{b}$ The dry pod yields are the mean of six replications of a repeated field experiment. $\pm=$ standard error of the mean. tion of chitin to soil at $1 \%(\mathrm{wt} / \mathrm{vol})$ increased the chitinolytic fungal and bacterial populations and significantly reduced Meloidogyne incognita infestation of cotton even in a second planting (17). Soil amendment of chitin increased the bacterial and actinomycete populations in fields with a history of severe Fusarium yellows of celery and reduced the disease incidence (3). Here, we have reported the use of native chitinolytic strains for the control of foliar diseases like LLS.

Production of extracellular chitinase(s) by GPS 5 and GRS 243 in the presence of chitin also might have contributed to the improved efficiency in control of LLS. Increase in the concentration of colloidal chitin, enhanced biocontrol of LLS further, indicating a possible relation between chitinolysis and disease control activities of both GRS 243 and GPS 5. Foliar spray of chitinsupplemented formulations improved the survival of chitinolytic $B$. cereus in the peanut phylloplane (22). Chitin- supplemented application of chitinolytic Stenotrophomonas maltophilia C3 improved the control of bean rust in the greenhouse (38), and leaf spot of Festuca arundinacea in the field (40), compared with that of C3 alone. A mixture of talc-based formulations of Pseudomonas fluorescens PF1 and FP7 along with chitin, when applied as a seed treatment and foliar spray, reduced sheath blight severity in rice similar to chemical fungicide (10). Seed treatment and soil drenching with suspensions of $B$. subtilis HS93, B. licheniformis LS674, and T. harzianum with $0.5 \%$ chitin were more effective against Phytophthora or Rhizoctonia root rot of pepper compared with the organisms without chitin (1).

Foliar spray of chitin-supplemented formulations of B. circulans GRS 243 and $S$. marcescens GPS 5 resulted in improved and consistent control of LLS in the field. Pod yields in chitin-supplemented GPS 5 treatment were comparable to chlorothalonil. The chitin-supplemented application of chitinolytic bacteria were reported to reduce the severity of rust in bean, but the yield increase in the field was inconsistent (38). The majority of the earlier attempts for biological control of LLS used mycoparasitic fungi and were limited by poor establishment of these fungi on the peanut phylloplane in the field (reviewed in literature citation 30). Different abiotic elicitors and plant growth-promoting rhizobacteria failed to induce systemic resistance and protect peanut against LLS disease in repeated greenhouse and field experiments (39). Chitin-supplemented $S$. marcescens GPS 5 significantly activated the defense-related enzymes, chitinase, $\beta$-1,3-glucanase, peroxidase, and phenylalanine ammonia lyase of peanut compared with GPS 5 and hence is expected to offer broad-spectrum

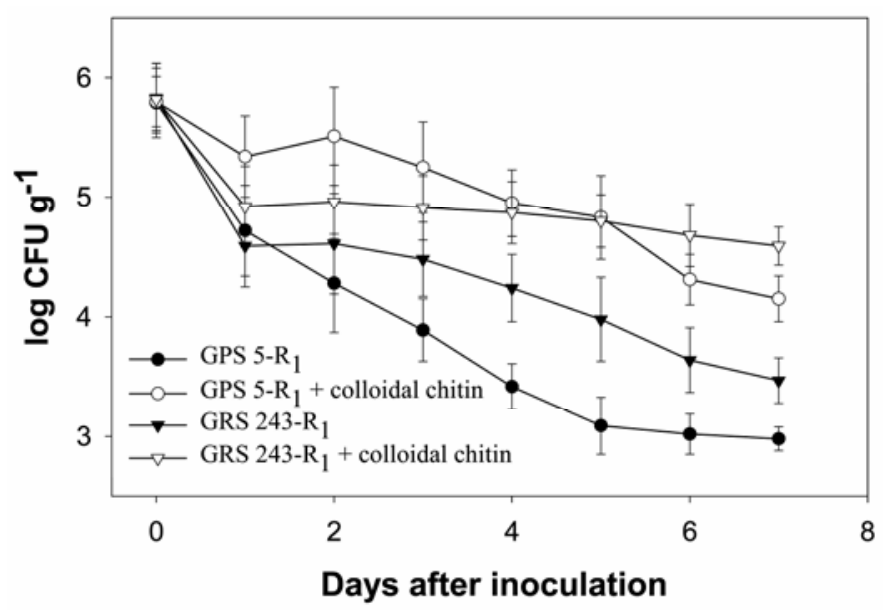

Fig. 4. Population dynamics of Bacillus circulans GRS 243 and Serratia marcescens GPS 5 applied with $1 \%$ colloidal chitin on the phylloplane of field-grown peanut. Rifampicin-resistant mutants of the two strains, GRS 243$\mathrm{R}_{1}$ and GPS 5-R $\mathrm{R}_{1}$, were used to study phylloplane colonization. Data points are the mean of six replications from a repeated experiment. The vertical bars of each data point represent the standard error of the mean. 
foliar disease control (20). In this context, chitin-supplemented application of chitinolytic bacteria, to reduce the dependency on chemical fungicides for LLS management, would be highly useful, especially deployed in combination with other bacterial strains with different modes of action in a consortium. Further, a combination of chitin-supplemented bacteria and moderate levels of host plant resistance may reduce or eliminate the need for fungicide applications. However, from a practical point of view cheaper sources of chitin should be developed as alternatives to colloidal chitin supplementation.

Supplementation of nutrients or other additives to the formulations of biocontrol agents is commonly practiced to increase their shelf-life. Supplementation of peat with chitin/spent compost/ Aspergillus niger mycelium enhanced the multiplication of $B$. subtilis AF 1 in peat, and also its biological control and plant growthpromoting activities (26). Chitin supplementation improved the shelf-life and biocontrol efficacy of GRS 243 and GPS 5 compared with bacteria formulated in peat alone, similar to performance of chitosan-amended formulation of chitinolytic bacterial strains $(4,33)$. Thus, GRS 243 and GPS 5, pre-induced for chitinase production, performed better in the phylloplane compared with freshly grown cells in LB broth or cells formulated in peat. Chitin supplementation of Stenotrophomonas maltophilia C3 cells pre-induced for chitinase production was more effective than similar treatment with noninduced cells in control of Bipolaris leaf spot on tall fescue and perennial ryegrass (41). Further, different carrier materials and chitin supplements need to be tested to develop formulations with improved activity in order to reduce the cost of bacterial preparations.

$S$. marcescens possesses a highly active chitinolytic system consisting of at least four enzymes and a chitin-binding protein (CBP) namely ChiA (57 to $58 \mathrm{kDa})$, ChiB (52 to $45 \mathrm{kDa}), C h i \mathrm{C} 1$ (48 to $52 \mathrm{kDa})$, ChiC2 (35 to $36 \mathrm{kDa}$ ), and CBP 21 (21 to $22 \mathrm{kDa}$ ) (8). Fuchs et al. (15) reported that individual chitinolytic enzymes from $S$. marcescens were not completely separated by several known purification techniques. The chitin-binding proteins of $S$. marcescens GPS 5 in this study were purified by gel filtration, which resulted in complete fractionation of the eluents of the

TABLE 4. Purification of a 55-kDa chitinase from the culture filtrate of Serratia marcescens GPS 5

\begin{tabular}{lccccc}
\hline Purification step & $\begin{array}{c}\text { Total pro- } \\
\text { tein (mg) }\end{array}$ & $\begin{array}{c}\text { Enzyme } \\
\text { units }^{\mathrm{a}}\end{array}$ & $\begin{array}{c}\text { Specific } \\
\text { activity }^{\mathrm{b}}\end{array}$ & $\begin{array}{c}\text { Purification } \\
\text { fold }\end{array}$ & $\begin{array}{c}\text { Yield } \\
(\%)\end{array}$ \\
\hline Culture filtrate & 455.0 & 4,732 & 10.4 & 1.0 & 100.0 \\
Affinity column & 12.1 & 1,238 & 102.3 & 9.8 & 26.2 \\
Sephadex G 100 & 9.0 & 1,081 & 120.1 & 11.5 & 22.8 \\
\hline
\end{tabular}

a One unit of enzyme activity is the amount of enzyme that released $1 \mu \mathrm{M} \mathrm{N}$ acetyl glucosamine $\mathrm{ml}^{-1} \mathrm{~h}^{-1}$ at $37^{\circ} \mathrm{C}$ and $\mathrm{pH} 5.2$.

${ }^{\mathrm{b}}$ Specific activity is the enzyme units per milligram of protein.

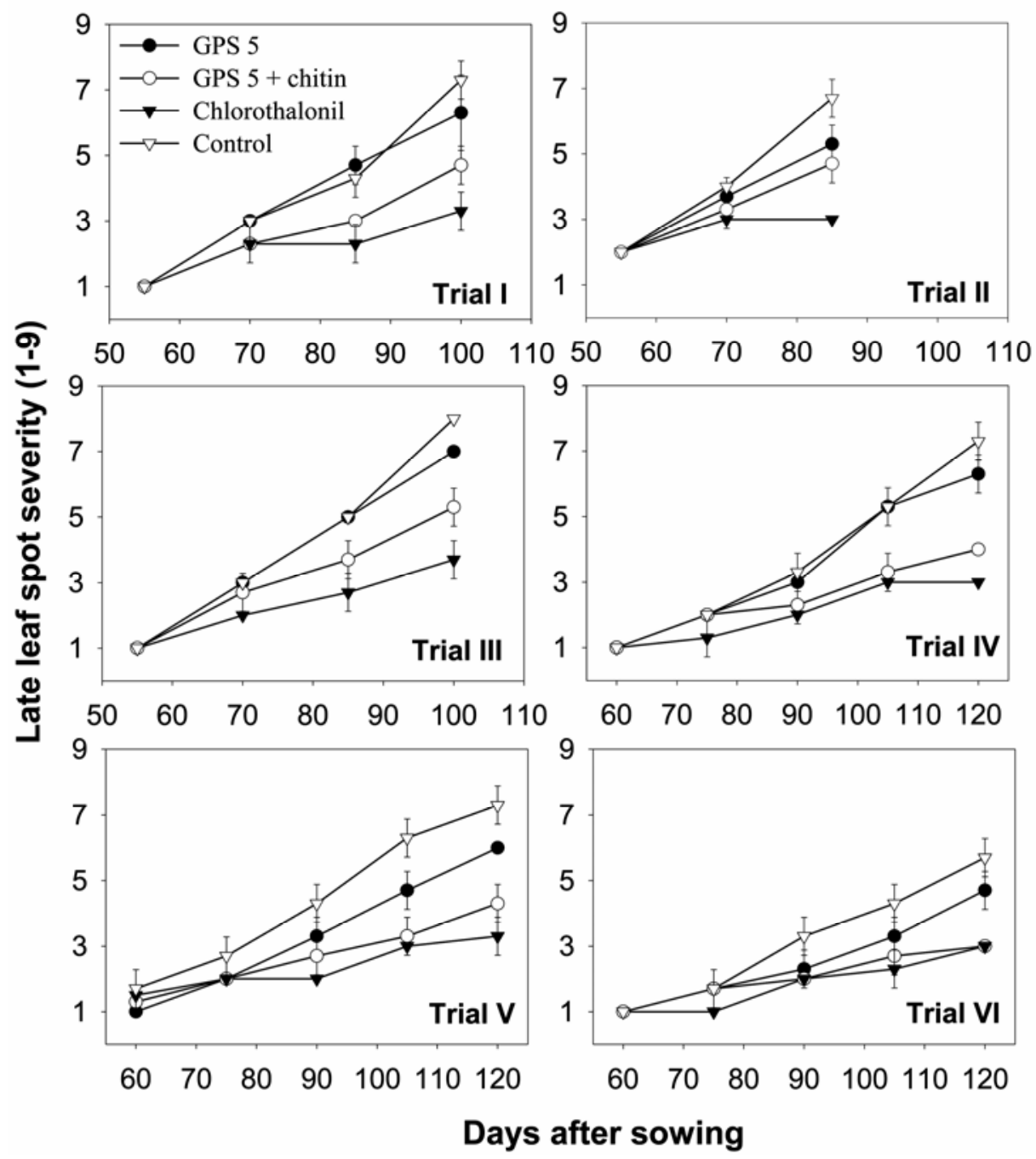

Fig. 5. On-farm evaluations of Serratia marcescens GPS 5 for control of late leaf spot of peanut. Trials I, II, and III were conducted in kharif 2003 (rainy season), and trials IV, V, and VI in rabi 2003 (post-rainy season). In each trial, the treatments were replicated three times. In trial II, the crop was harvested early to avoid terminal drought. In trial VI, the plant population density and growth was less, resulting in poor canopy and late leaf spot development. Each data point is the mean of three replications. For some data points, the standard error of the mean was very small and hence is not visible. 
affinity column. Separation of the two chitin-binding proteins with SDS-PAGE followed by activity staining revealed the enzymatic action of a $55-\mathrm{kDa}$ protein, while the $21-\mathrm{kDa}$ protein had no detectable enzymatic activity. Enzyme recovery after gel filtration was $22.9 \%$. Roberts and Cabib (31) recovered $27.5 \%$ of the initial chitinase activity. The two chitin-binding proteins of $S$. marcescens GPS 5, eluted from Sephadex G 100 and separated on SDSPAGE, revealed the monomeric nature of the $55-\mathrm{kDa}$ chitinase and dimeric nature of the $21-\mathrm{kDa}$ chitin-binding protein; their molecular weights matched with the reported chitinases of $S$. marcescens (8).

The 55-kDa chitinase of GPS 5 inhibited the in vitro conidial germination of $P$. personata in a concentration-dependent manner. Antifungal activity of chitinases and the resultant lysis of germ tubes has been reported frequently. Purified chitinase of Fusarium chlamydosporium inhibited the urediniospore germination of Puccinia arachidis in a concentration-dependent manner and lysed the walls of urediniospores (27). Degradation of hyphae of Sclerotium rolfsii in the presence of chitinase of $S$. marcescens was observed, and $63 \%$ of the cells of the hyphal tips lysed (29).

Foliar application of chitinase caused a significant reduction in LF in this study. Also, cell-free culture filtrate of GPS 5 grown in minimal medium with colloidal chitin as a carbon source had a significant suppressive effect on LLS. Chitinase-based preparations for plant disease control have resulted in varying levels of disease control. A fourfold decrease in the severity of spur blight of raspberry was observed after foliar application of a chitinase preparation (32). Chitinase E (family 19; class IV) from a yam (Dioscorea opposita) protected fruit and leaves of strawberry from powdery mildew infection, and the disease protection lasted for 2 weeks. The enzyme degraded the hyphae and conidia of Sphaerotheca humuli with no harmful effects on the strawberry plants (18).

Results of this study suggest the possibility of developing a suitable foliar spray for control of LLS of peanut with chitinolytic bacteria. The chitinolytic ability of the bacteria can be exploited to develop improved formulations with increased shelf-life and better survival in the phylloplane. Further evaluation of Serratia chitinases for control of foliar diseases of peanut would help in developing nonchemical methods for control of LLS disease.

\section{ACKNOWLEDGMENTS}

The Andhra Pradesh-Netherlands Biotechnology Programme supported this work in the form of a research grant to A. R. Podile and senior research fellowship to G. K. Kishore. We thank the UGC-SAP and DSTFIST programmes of the Department of Plant Sciences, University of Hyderabad.

\section{LITERATURE CITED}

1. Ahmed, A. S., Ezziyyani, M., Sanchez, C. P., and Candela, M. E. 2003. Effect of chitin on biological control activity of Bacillus spp. and Trichoderma harzianum against root rot disease in pepper (Capsicum annuum) plants. Eur. J. Plant Pathol. 109:633-637.

2. Beattie, G. A., and Lindow, S. E. 1999. Bacterial colonization of leaves: A spectrum of strategies. Phytopathology 89:353-359.

3. Bell, A., Hubbard, J. C., Liu, L., Davis, R. M., and Subbarao, K. V. 1998. Effects of chitin and chitosan on the incidence and severity of Fusarium yellows of celery. Plant Dis. 82:322-328.

4. Benhamou, N., Kloepper, J. W., and Tuzun, S. 1998. Induction of resistance against Fusarium wilt of tomato by combination of chitosan with an endophytic bacterial strain: Ultrastructure and cytochemistry of the host response. Planta 204:153-168.

5. Blakeman, J. P. 1982. Potential for biological control of plant diseases on the phylloplane. Annu. Rev. Phytopathol. 20:167-192.

6. Boller, T., and Mauch, F. 1988. Colorimetric assay for chitinase activity. Method. Enzymol. 161:430-435.

7. Bradford, M. M. 1976. A rapid and sensitive method for quantitation of microgram quantities of protein utilizing the principle of protein-dye binding. Anal. Biochem. 72:248-254.
8. Brurberg, M. B., Synstad, B., Klemsdal, S. S., van Aalten, D. M. F., Sundheim, L., and Eijsink, V. G. H. 2001. Chitinases from Serratia marcescens. Recent Res. Devel. Microbiol. 5:187-204.

9. Clifford, B. C. 1973. The construction and operation of a dew simulation chamber. New Phytol. 77:619-623.

10. Commare, R. R., Nandakumar, R., Kandan, A., Suresh, S., Bharathi, M., Raguchander, T., and Samiyappan, R. 2002. Pseudomonas fluorescens based bio-formulation for the management of sheath blight disease and leaffolder insect in rice. Crop Prot. 21:671-677.

11. Dipetro, A., Lorito, M., Hayes, C. K., Broadway, R. M., and Harman, G. E. 1993. Endochitinase from Gliocladium virens: Isolation, characterization and synergistic antifungal activity in combination with gliotoxin. Phytopathology 83:308-313.

12. Downing, K. J., and Thomson, J. A. 2000. Introduction of the Serratia marcescens chiA gene into an endophytic Pseudomonas fluorescens for the biocontrol of phytopathogenic fungi. Can. J. Microbiol. 46:363-369.

13. El-Katatny, M. H., Gudelj, M., Robra, K. H., Elnaghy, M. A., and Gubitz, G. M. 2001. Characterization of a chitinase and an endo- $\beta$-1,3-glucanase from Trichoderma harzianum Rifai T24 involved in control of the phytopathogen Sclerotium rolfsii. Appl. Microbiol. Biotechnol. 56:137-143.

14. Frankowski, J., Lorito, M., Scala, F., Schmid, R., Berg, G., and Bahl, H. 2001. Purification and properties of two chitinolytic enzymes of Serratia plymuthica HRO-C48. Arch. Microbiol. 176:421-426.

15. Fuchs, R. L., McPherson, S. A., and Drahos, D. J. 1986. Cloning of a Serratia marcescens gene encoding chitinase. Appl. Environ. Microbiol. 51:504-509.

16. Gomes, R. C., Semedo, L. T. A. S., Soares, R. M. A., Linhares, L. F., Ulhoa, C. J., Alviano, C. S., and Coelho, R. R. R. 2001. Purification of a thermostable endochitinase from Streptomyces RC1071 isolated from a cerrado soil and its antagonism against phytopathogenic fungi. J. Appl. Microbiol. 90:653-661.

17. Hallmann, J., Rodriguez-Kabana, R., and Kloepper, J. W. 1999. Chitinmediated changes in bacterial communities of the soil, rhizosphere and within roots of cotton in relation to nematode control. Soil Biol. Biochem. 31:551-560.

18. Karasuda, S., Tanaka, S., Kajihara, H., Yamamoto, Y., and Koga, D. 2003. Plant chitinase as a possible biocontrol agent for use instead of chemical fungicides. Biosci. Biotechnol. Biochem. 67:221-224.

19. Kishore, G. K., Pande, S., and Podile, A. R. 2005. Biological control of collar rot disease with broad-spectrum antifungal bacteria associated with groundnut. Can. J. Microbiol. 51:123-132.

20. Kishore, G. K., Pande, S., and Podile, A. R. 2005. Chitin-supplemented foliar application of Serratia marcescens GPS 5 improves control of late leaf spot disease of groundnut by activating defense-related enzymes. J. Phytopathol. 153:169-173.

21. Kishore, G. K., Pande, S., Rao, J. N., and Podile, A. R. 2003. Evaluation of chitinolytic strains of Serratia marcescens and Bacillus circulans for biological control of late leaf spot of groundnut. Pages 19-20 in: Proc. National Seminar on Stress Management in Oilseeds for Attaining SelfReliance in Vegetable Oils, Directorate of Oil Seeds Research, Hyderabad, India.

22. Kokalis-Burelle, N., Backman, P. A., Rodriguez-Kabana, R., and Ploper, L. D. 1992. Potential for biological control of early leafspot of peanut using Bacillus cereus and chitin as foliar amendments. Biol. Control 2:321-328

23. Laemmli, U. K. 1970. Cleavage of structural proteins during the assembly of the head bacteriophage T4. Nature 227:680-685.

24. Limon, M. C., Pintor-Toro, J. A., and Benitez, T. 1999. Increased antifungal activity of Trichoderma harzianum transformants that overexpress a 33-kDa chitinase. Phytopathology 89:254-261.

25. Manjula, K., Kishore, G. K., and Podile, A. R. 2004. Whole cells of Bacillus subtilis AF 1 proved more effective than cell free and chitinasebased formulations in biological control of citrus fruit rot and groundnut rust. Can. J. Microbiol. 50:737-744.

26. Manjula, K., and Podile, A. R. 2001. Chitin-supplemented formulations improve biocontrol and plant growth promoting efficiency of Bacillus subtilis AF 1. Can. J. Microbiol. 47:618-625.

27. Mathivanan, N., Kabilan, V., and Murugesan, K. 1998. Purification, characterization, and antifungal activity of chitinase from Fusarium chlamydosporum, a mycoparasite to groundnut rust, Puccinia arachidis. Can. J. Microbiol. 44:646-651.

28. McDonald, D., Subrahmanyam, P., Gibbons, R. W., and Smith, D. H. 1985. Early and late leaf spots of groundnut. Information Bull. 21. International Crops Research Institute for the Semi-Arid Tropics, India.

29. Ordentlich, A., Elad, Y., and Chet, I. 1988. The role of chitinase of Serratia marcescens in biocontrol of Sclerotium rolfsii. Phytopathology 78:84-88.

30. Podile, A. R., and Kishore, G. K. 2002. Biological control of peanut diseases. Pages 131-160 in: Biological Control of Major Crop Plant Diseases. S. S. Gnanamanickam, ed. Marcel Dekker, New York. 
31. Roberts, R. L., and Cabib, E. 1982. Serratia marcescens chitinase: Onestep purification and use for the determination of chitin. Anal. Biochem. 127:402-412.

32. Shternshis, M. V., Beljaev, A. A., Shpatova, T. V., Bokova, J. V., and Duzhak, A. B. 2002. Field testing of BACTICIDE, PHYTOVERM and CHITINASE for control of the raspberry midge blight in Siberia. Biocontrol 47:697-706.

33. Singh, P. P., Shin, Y. C., Park, C. S., and Chung, Y. R. 1999. Biological control of Fusarium wilt of cucumber by chitinolytic bacteria. Phytopathology 89:92-99.

34. Subrahmanyam, P., McDonald, D., Gibbons, R. W., Nigam, S. N., and Nevill, D. J. 1982. Resistance to rust and late leafspot diseases in some genotypes of Arachis hypogaea. Peanut Sci. 9:6-10.

35. Subrahmanyam, P., McDonald, D., and Rao, P. V. S. 1983. Influence of host genotype on uredospore production and germinability in Puccinia arachidis. Phytopathology 73:726-729.

36. Subrahmanyam, P., McDonald, D., Waliyar, F., Reddy, L. J., Nigam, S. N., Gibbons, R. W., Rao, V. R., Singh, A. K., Pande, S., Reddy, P. M., and Rao, P. V. S. 1995. Screening methods and sources of resistance to rust and late leaf spot of groundnut. Information Bull. No. 47. Inter- national Crops Research Institute for the Semi-Arid Tropics, Andhra Pradesh, India.

37. Trudel, J., and Asselin, A. 1989. Detection of chitinase activity after polyacrylamide gel electrophoresis. Anal. Biochem. 178:362-366.

38. Yuen, G. Y., Steadman, J. R., Lindgren, D. T., Schaff, D., and Jochum, C. 2001. Bean rust biological control using bacterial agents. Crop Prot. 20:395-402.

39. Zhang, S., Reddy, M. S., Kokalis-Burelle, N., Wells, L. W., Nightengale, P., and Kloepper, J. W. 2001. Lack of induced systemic resistance in peanut late leaf spot disease by plant growth-promoting rhizobacteria and chemical elicitors. Plant Dis. 85:879-884.

40. Zhang, Z., and Yuen, G. Y. 1999. Biological control of Bipolaris sorokiniana on tall fescue by Stenotrophomonas maltophilia strain C3. Phytopathology 89:817-822.

41. Zhang, Z., and Yuen, G. Y. 2000. Effects of culture fluids and preinduction of chitinase production on biocontrol of Bipolaris leaf spot by Stenotrophomonas maltophilia C3. Biol. Control 18:277-286.

42. Zhang, Z., and Yuen, G. Y. 2000. The role of chitinase production by Stenotrophomonas maltophilia strain C3 in biological control of Bipolaris sorokiniana. Phytopathology 90:384-389. 